\title{
RESEARCH METHODOLOGY FOR THE ASSESSMENT OF THE INFLUENCE OF ORGANIZATIONAL CULTURE ASPECTS ON PROJECT SUCCESS
}

\author{
Ol'ga Yu. Isopeskul' \\ ORCID ID: 0000-0002-0736-534X, Researcher ID: L-6072-2015, e-mail: oisopeskul@ hse.ru \\ Ekaterina A. Ponomarenko \\ ORCID ID: 0000-0002-9234-725X , e-mail: wittmannekaterina@gmail.com
}

\author{
National Research University Higher School of Economics (38, Studencheskaya st., Perm, 614070, Russia)
}

\begin{abstract}
Recently the global trend to organize the activities of companies in different spheres and sectors of the economy on the project principle has become more relevant and acute. Heads of companies currently pay particular attention to the assessment of the result of the project and find the factors that affect its success. At the first stage of development of this problem, the researchers focused on the study of the indicators of the "iron triangle", on the achievement the strategic goals of the company or on the meeting the interests of the project customers. Contemporary scholars focus on a wider range of project success factors, their ambiguity and multi-dimensionality. Organizational culture of a project is one of the most important factors as, on the one hand, its impact is well recognised, but on the other hand it is difficult to identify its impact as the culture interacts with other factors. Therefore, it is difficult to determine the boundaries of the impact. However, extending the success factors of a project to include aspects of organizational culture provides managers with an additional tool to achieve project results. The purpose of the article is to test the OCPS (Organizational Culture - Projects Successful) method that has been modified by the author according to the features of the Russian economy. The method allows determining the impact of organizational culture on the project success in different branches of activity. The research is based on a systematic and synergistic approach that considers the project success as a complex system in which the effect of the control action is not directly proportional to the efforts made. This is due to a wide range of possible factors that affect the success of the project, a high degree of uncertainty of the environment, as well as a variety of internal impulses of an organization. The method has been applied and tested in the case study of companies operating in a construction industry as a project is the main type of business for them. In this sector of economy, projects can attract large cash flows. However, unsuccessful projects lead to financial instability of a company. Qualitative and quantitative methods have been used in the study. The main results that have been obtained are 1) the determined aspects of organizational culture that affect the project success in the organisations operating in construction industry of economy: teambuilding, external communication and leadership; 2) the generation of criteria for their assessment and recommendations on the use of the identified aspects of organizational culture in order to increase the probability of success of construction projects. For this purpose a matrix of levels of success of construction projects has been proposed. The application of the matrix allows quickly responding to the problems existing in the project team. The obtained scientific results will allow project managers to get an additional tool to study the aspects that affect the success of an organization's projects, as well as to identify the elements, influencing on which increases the opportunity to achieve project results. Further studies will be devoted to the testing of the suggested method in the case study of projects made by companies operating in other branches of economy. Subsequently, it will verify the method in the context of applicability to organizations regardless of their sphere of activity.

Keywords: project management, project success, organizational culture, organizational culture aspects, project efficiency, OCPS methods, construction industry of economy, institutional peculiarities.
\end{abstract}




\title{
МЕТОДИКА ИССЛЕДОВАНИЯ АСПЕКТОВ ВЛИЯНИЯ ОРГАНИЗАЦИОННОЙ КУЛЬТУРЫ НА УСПЕХ ПРОЕКТА
}

\author{
Ольга Юрьевна Исопескуль \\ ORCID ID: 0000-0002-0736-534X, Researcher ID: L-6072-2015, e-mail: oisopeskul@ @se.ru \\ Екатерина Александровна Пономаренко \\ ORCID ID: 0000-0002-9234-725X, e-mail: wittmannekaterina@ gmail.com
}

Национальный исследовательский университет «Высшая школа экономики» - Пермский филиал

(Россия, 614070, г. Пермь, Студенческая, 38)

В последние десятилетия актуализируется общемировая тенденция организовывать деятельность компаний в разных сферах и отраслях экономики по проектному принципу. Для руководителей организаций становится значимым вопрос оценки результата проекта и нахождения тех факторов, которые влияют на его успех. На первом этапе разработки данной проблемы исследователи были сконцентрированы на изучении показателей «железного треугольника», на достижении стратегических целей компании или на удовлетворении интересов заказчика проекта. Современные исследования акцентируют внимание на более широком спектре факторов успеха проекта, их неоднозначности и многомерности. Среди таких факторов особое место занимает организационная культура проекта, влияние которой, с одной стороны, общепризнанно, а с другой - сложно идентифицируемо, поскольку она взаимодействует с другими факторами. В результате сложно определить границы такого влияния. Вместе с тем расширение факторов успеха проекта с включением в них аспектов организационной культуры дает менеджерам дополнительный инструмент для достижения результатов проекта. Целью статьи является апробация модифицированной авторами с учетом особенностей российской экономики методики OCPS (Organizational Culture - Projects Successful), позволяющей выявить аспекты влияния организационной культуры на успех проекта в различных сферах деятельности. В методологической основе исследования лежит системносинергетический подход, рассматривающий успех проекта как сложную систему, в которой эффект управляющего воздействия не прямо пропорционален приложенным усилиям. Это обусловливается широким спектром возможных факторов, влияющих на успех проекта, высокой степенью неопределенности среды, а также разнообразием внутренних импульсов деятельности организации. Алгоритм применения данной методики проиллюстрирован на примере компаний строительной отрасли экономики, для которых проектная деятельность является базовой формой ведения бизнеса. В данной отрасли экономики проекты позволяют привлекать большие потоки денежных средств, в случае неудачных проектов существенно страдает финансовая результативность деятельности организации. Исследование базировалось на использовании как качественных, так и количественных методов. Основными результатами стали: 1) определение аспектов организационной культуры, влияющих на успех проектов организаций строительной отрасли экономики: командообразование, внешние коммуникации, лидерство; 2) формирование критериев их оценки и рекомендаций по использованию выявленных аспектов организационной культуры для повышения вероятности достижения успеха строительных проектов. С этой целью предложена матрица уровней успеха строительных проектов, применение которой позволяет оперативно реагировать на проблемы, существующие в команде проекта. Представленные научные результаты позволят менеджерам проектов получить дополнительный инструмент для исследования аспектов, влияющих на успех проектов организации, а также выявить элементы, воздействуя на которые увеличивается вероятность достижения результатов проекта. В качестве перспективных направлений исследований предполагается апробация предложенной методики на проектах, реализуемых организациями, функционирующими в других отраслях экономики, что в дальнейшем позволит верифицировать ее в контексте применимости к организациям независимо от сферы их деятельности.

Ключевые слова: управление проектом, успех проекта, организационная культура, аспекть организационной культуры, результативность проекта, методика ОСРS, строительная отрасль экономики, институциональные особенности.

Introduction

7 he application of project management in different spheres and branches of economy is currently becoming a global trend. Herewith, the problem of evaluating the project results and finding the factors that determine its success is becoming acute and important.

Organizational culture is a unique tool that allows achieving the goals of an 
organization through the influence on the organizational behavior of staff. In the modern context the activity of management in this area is a decisive factor to ensure the competitiveness of any enterprise. The impact of organizational culture on the company efficiency has been empirically proven in the works by B.T. Gregory, S.G. Harris, A. Armenakis and C.L. Shook [1], D. Denison, L. Neiminen and L. Kotrba [2], L.C. Harris and E. Ogbonna [3], G.G. Gordon and N. Ditomaso [4], R. Calori and Ph. Sarnin [5], L. Kotrba, M. Gillespie, A.M. Schmidt, etc. [6]. Meanwhile the issue of correlation between project success and organizational culture is insufficiently developed both in the foreign theory and practice of management, and in the Russian research field. The studies that currently exist tend to focus on the analysis of derivatives of organizational culture-communication style, knowledge transmission, climate of the project team, etc. In our opinion, this situation is due to the fact that organizational culture refers to difficult to identify factors, as it interacts with other factors that affect the success of a project. However, we believe that the extension of the number of project success factors that will also include aspects of organizational culture in the list can offer managers additional tools for achieving project success.

The purpose of the article is to test a OCPS (Organizational Culture - Projects Successful) method that has been modified by the author according to the features of the Russian economy. The methodology allows determining the impact of organizational culture on the project success in different branches of activity.

The purpose determines the structure of the article. Different concepts of project success, its factors and evaluation tools are analyzed in the first part. The second part is devoted to theoretical approaches that reveal the relationship between the success of a project and the organizational culture. The third section describes the developed methodology for studying the impact of organizational culture on the success of the project. In conclusion, the results are summarized.
Theoretical and methodological foundations for the investigation of project factors

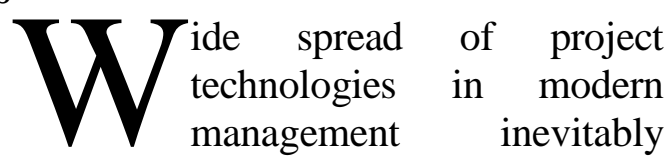
raises the question of the factors that determine the success of a project.

According to K. Davis over the past 50 years, the concept of project success has experienced several waves of interest [7].

The first wave (1970-1980) is characterized by technical interpretation of project success in the concepts of "iron triangle".

During the period 1980-1990, there was a shift of emphasis from technical aspects towards the customer and project team. Numerous attempts have been made to link project success with it being understood by the stakeholders, who expanded the "iron triangle" [8]. The concept of critical success factors appeared.

Over the 1990s and the 2000s the groundwork for the modern understanding of project success was laid with creation of project management standards and success concepts as well as life-cycle theories and strategic linking of the project and company goals. The success of a project becomes a tangible value, the authors of scientific articles seek to find those aspects, influencing on which will help to achieve the necessary results.

Currently, researchers offer a broad pool of project success definitions of "project success". In particular, H. Kerzner and F. Saladis believe that the project success is a situation "when the expected business value is achieved within the limits of imposed constraints and assumptions" [9, p. 62]. A. Rolstandas determines the project success as synergy of solving the three problems: project problems, or the tasks of achieving the "iron triangle"; business problems, or tasks set by the customer; and socially-objective problems, or tasks that are seen by the local community representatives, affected by the project result [10, p. 14]. Similar interpretation is suggested by A. Shenhar and D. Dvir, who suggest that the project success is benefits 
received by the organization and the consumer, i. e. the prospects that the project opens for the performer, the team satisfaction and the project effectiveness [11, p. 94].

The variety of approaches to the definition of the concept "project success" naturally introduces a controversial element in the question of tools for its assessment.
L.A. Ika suggests to identify the project success using factor and criteria of success. According to the scholar's opinion success criteria are becoming numerous and factors are accumulated into complex ambiguous and multidimensional categories [12, p. 16].

Modern researchers suggest different sets of factors, the dynamics of which is shown in Fig. 1.

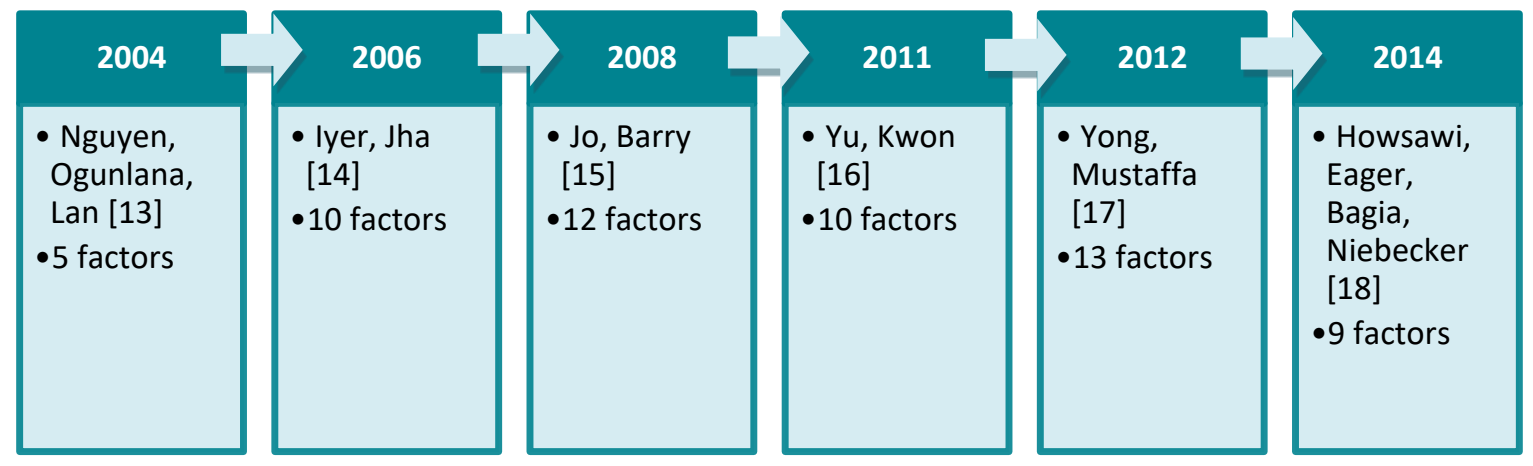

Fig. 1. The number of factors in the studies during 2004-2014*

* Developed by the authors according to [12; 18].

According to Fig. 1, over the past decade the number of key success factors has steadily increased. In addition, there is a substantial variety of them (Fig. 2).

\begin{tabular}{|c|c|c|}
\hline $\begin{array}{c}\text { Nguyen, Ogunlana, Lan } \\
\text { (2004) }\end{array}$ & lyer, Jha (2006) & Jo, Barry (2008) \\
\hline $\begin{array}{l}\text { - Amount and accessibility of } \\
\text { resources } \\
\text { - Sufficient financing } \\
\text { - Competent team of a project } \\
\text { - A competent manager of a } \\
\text { project } \\
\text { - Loyalty to a project }\end{array}$ & $\begin{array}{l}\text { - Favorable working conditions } \\
\text { - Sufficient financing } \\
\text { - Communications } \\
\text { - A competent customer } \\
\text { - A competent manager of a } \\
\text { project } \\
\text { - Loyalty to a project } \\
\text { - Monitoring and feedback } \\
\text { - A competent team of a } \\
\text { project } \\
\text { - Support of a project } \\
\text { - Coordination }\end{array}$ & $\begin{array}{l}\text { - Accurate planning } \\
\text { - Sufficient financing } \\
\text { - Interested parties } \\
\text { - Lessons learned } \\
\text { - Competent team of a project } \\
\text { - A competent manager of a } \\
\text { project } \\
\text { - Feedback with a client } \\
\text { - Project supported by a top- } \\
\text { manager } \\
\text { - Permanent employment of a } \\
\text { manager } \\
\text { - Post-project analysis } \\
\text { - Project developed according } \\
\text { to the company's aims } \\
\text { - Project monitoring and } \\
\text { feedback }\end{array}$ \\
\hline
\end{tabular}

Fig. 2. Key factors of project success in the studies of foreign scientists during 2004-2008

Fig. 2 reflects a significant expansion of success factors in the period from 2004 to 2006. Researchers began to take into account the role of internal communications of the project, project monitoring, etc. According to L.A. Ika, it shifted the focus from easily identifiable success factors to more symbolic ones [12] (Fig. 3). 


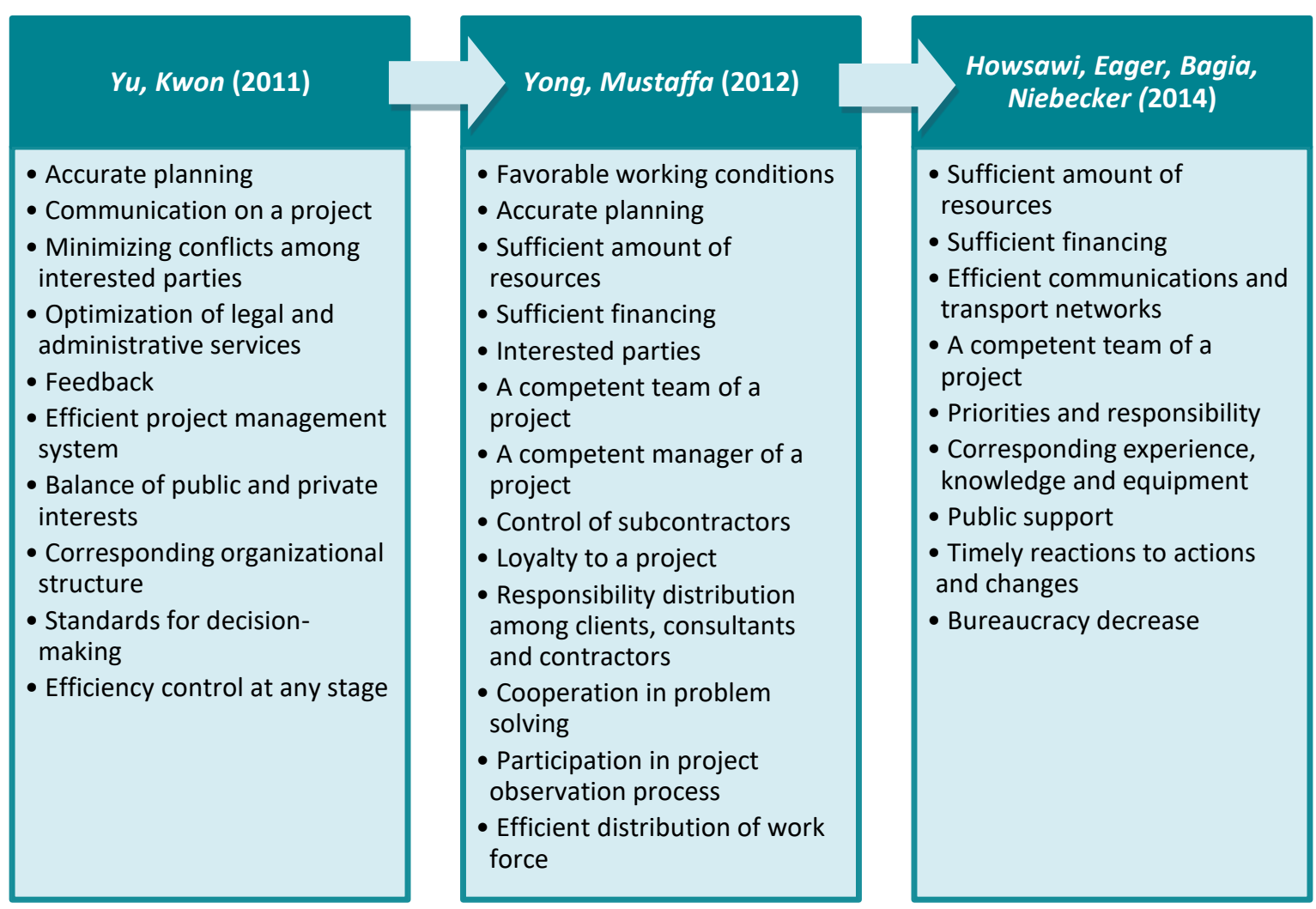

Fig. 3. Key factors of project success in the studies of foreign scientists during 2011-2014*

* Developed by the authors according to [18].

Fig. 3 indicates that over the following years, the authors of the studies introduced new factors or detailed previous ones. As a rule, the most frequently mentioned factors in modern publications are the following (Fig. 4).

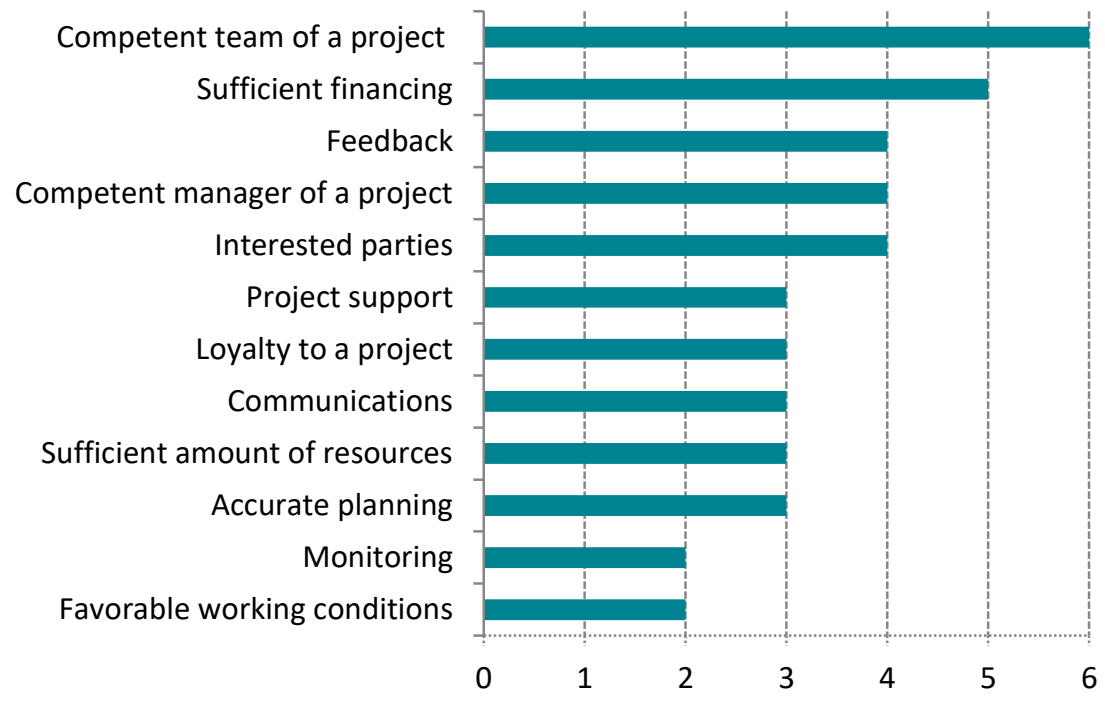

Fig. 4. Recurring key success factors

We will consider the success factors presented in Fig. 4 in the context of their differentiation into standard and symbolic.

A standard group of factors can be identified using Gantt charts, milestones, and budget and reserve financial planning. This group includes: project monitoring, sufficient funding, sufficient resources, the competence of the project team, measured by the amount of available knowledge, the presence of stakeholder participation - contractors, customers, and end users. 
The measurement of symbolic factors is a time consuming process. The group of symbolic factors includes favorable working conditions, communication, loyalty to the project, support of the project by the company's society, a competent project Manager in the context of his leadership qualities, detailed planning as a method of work in a particular project, as well as feedback.

The research over the past decade has shown a shift in focus from easily identifiable reasons for success, such as the level of project funding, to more rhetorical and hard to define ones. Organizational culture is one of these factors that are hard to define.

The relationship between organizatio nal culture and project success: An overview of key approaches

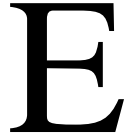

very year a significant number of researchers pay attention to the correlation of different aspects of organizational culture and project results. According to C.C. Iroanya, culture has a significant impact on the outcome of the project, as the project team in its initiation, goalsetting and task setting are guided by the established culture [19].

Some scholars believe that the project results are affected by the type of organizational culture of a company. The researchers identifying the most favorable culture for project efficiency share the opinion that "bureaucracy" does not lead to project success $[12 ; 19 ; 20]$.
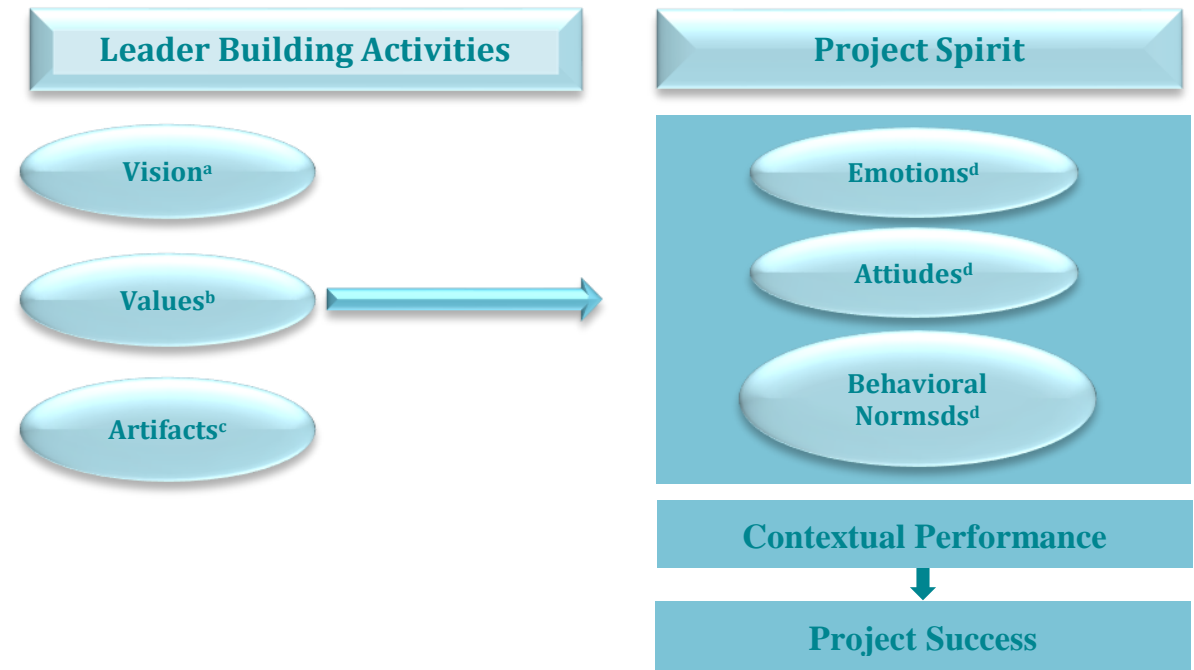

[21], when studied the works by colleagues have identified twelve aspects of the organizational culture, the synergies of which are able to lead the project to success:

- flexibility and innovations;

- international integration;

- process and relations standardization;

- focus on market;

- open communications;

- support by a leader;

- emphasis on people;

- emphasis on personal competences and their development;

- decentralized decision-making;

- accurate strategic planning;

- rational decision-making;

- result orientation.

M. Latonio reduced the number of organizational culture aspects influencing the project success to six: 1) the influence of a leader/manager of a project; 2) comprehension of project success; 3) values; 4) communications; 5) emphasis on people; 6) correspondence to the organization values [22].

Particular attention is paid to the project leader's influence, understanding the project success, its values, communication, focus on people, and matching the organization's objectives [22].

Z.H. Aronson, A.J. Shenhar, P. Patanakul also included a leadership factor in their project success model (Fig. 5).

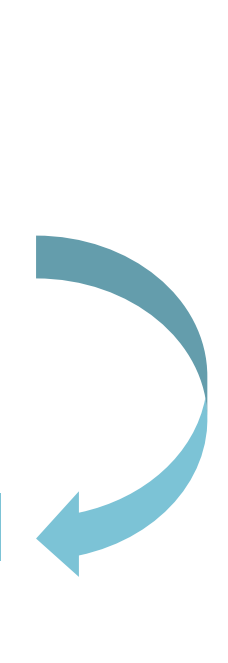

Fig. 5. Model of the impact of organizational culture on project success [23, p. 36]

Note: ${ }^{\mathrm{a}}$ Vision effectively articulated by the project leader; ${ }^{\mathrm{b}}$ Project leader-instilled values; ${ }^{\mathrm{c}}$ Artifacts instilled by the project leader; ${ }^{\mathrm{d}}$ Project spirit expression components. 
According to the researchers, the project artifacts, values and vision (in this case the vision of a project) as elements of the organizational culture structure are subject to the leader's influence [23]. Then the project culture and its spirit are developed, relationship between participants is established, and behaviour patterns are set. A general behaviour pattern, leading to success, emerges within the project. At the same time, the researchers mention that the behavior pattern should match the project, emphasize its value, while the participants should demonstrate their project loyalty and be ready to adjust their activities to the changing environment [23, p. 39].

Considering organizational culture as a multi-component, complex and deep organizational phenomenon, we believe that it inevitably affects all aspects of the company life, including project activities. At the same time, organizational culture is one of the most important factors in the system, that determine both the success of the project and the effectiveness of the project team. An adequate assessment of the impact of organizational culture and its management will allow project managers not only to neutralize the risk of failure, but also to obtain additional benefits.

OCPS method for the investigation of the impact of organizational culture on project success

he issue of organizational
culture influence on the project
success is quite new and requires further theoretical study and instrumental filling. Being, on the one hand, a multidimensional and complexly managed construct, and, on the other hand, having a significant impact on employees' organizational behavior, culture has, in our opinion, a great potential for influencing project success, in case we identify organizational culture elements that have the greatest impacting capacity. However, even within the foreign field of study, characterized by greater research completeness, there are a limited number of methods to determine aspects of organizational culture impact on project success (methods suggested by J.D. Wilfong, M. Latinio, Z.H. Aronson,
A.J. Shenhar and P. Patanakul). In Russia, given the lack of research in this area, such methods seem to be very few. In this regard, we consider it important to present a tool that will reveal the role of culture to ensure the success of a project.

Conventional methods that are currently used to study the impact of organizational culture on project success are focused either in qualitative methods, or focused on their combination with quantitative methods. The method we suggest is focused on the second approach. The tool we have developed is called OCPS (organizational culture - projects successful).

The method includes two stages:

- an interview to identify a set of organizational culture aspects influencing the project success in the Russian environment. We think it is not appropriate to adopt a list of aspects proposed by foreign researchers for questioning Russians due to the significant difference in mentalities and business practices. When conducting interviews and decoding them we used the methods suggested by J.D. Wilfong and M. Latonio [22; 24];

- a survey to confirm or refute the results obtained on the first stage. The questionnaires were made and calculation tools was carried out on the basis of adapted questionnaires developed by J.D. Wilfong and A.J. Shenhar, P. Patanakul and Z.H. Aronson [23; 24].

The sample for interview participants includes experts implementing projects in a specific field for at least a year, working in the company for at least two years, and being involved in both failed and successful projects.

The interview structure included two blocks, notionally named "a successful project" and an "unsuccessful project". We consider the project successful if it has ended on time, within the budget and satisfied the participants and customers of the project. The unsuccessful project is the one where the stakeholders have not been satisfied with the result, and the resources (time, financial and human) spent have not brought the expected impact. 
The analysis of the obtained data was carried out in accordance with the principles of the realistic analysis of $\mathrm{V}$. Braun and V. Clarke [25]. It was employed to discover the latent level of understanding the phenomenon under consideration through respondents' experience, meaning and reality.

Realistic analysis of the interview consists of six stages. The first is transcription of the interview and initial acquaintance with the material. The second stage is the creation of source codes, which can be search guidelines within the interview. We used the following codes: values, leader behavior, team atmosphere, relationships with third parties, attitude to time, budget and project result. Further elaboration of the codes depends on the field in which the study is conducted. The third, fourth and fifth stages are designed to either find the codes that were originally formulated, or to recognize their absence. The result of these stages is the formation of "themes", on the basis of which the final set of aspects is formulated at the final stage. These aspects will be verified at the next stage of the method - the questionnaire.

An online survey in thematic communities has been also used to accumulate as many opinions as possible to test the hypothesis about the impact of aspects identified through interviews on the success of the project. We also involved in the survey those organizations whose participants were experts at the first stage to summarize the results and ensure greater reliability of the study.

In our questionnaire the success of the project is the dependent variable, which is influenced by independent variables identified aspects of the organizational culture of the project.

The quantitative research analysis was carried out with the help of special programs. All questions are evaluated from the point of view of coherence of the phenomenon which they describe.

The result was finding the influence of aspects - independent variables - on the success of the project - dependent variable - through linear regressions, as well as finding the optimal combination of aspects of influence on success. Thus, the results of the questionnaire allow us make the conclusion about how the aspects identified in the interview really affect the success of the project in a particular industry.

We will illustrate the presented method in the framework of project assessment in the construction sector, in which the project form of organization of activity is considered to be the main one. The project is an important management tool, and design is an essential stage of the investment cycle. Construction projects tend to be largescale, attracting significant cash flows. In case of unsuccessful projects, the financial performance of the organization and its reputation suffer significantly, and therefore the question of the success of construction projects and the factors that influence this success is one of the most important in the context of project management.

\section{Testing the OCPS method at enterprises operating in the construction branch of Russian economy

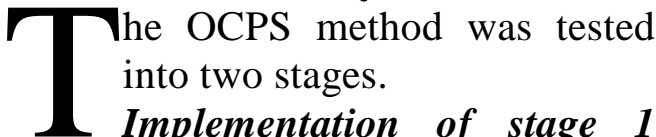
suggests accurate selection of an expert group. Our group of experts included 12 employees of three largest construction companies in Perm, which have comparable performance indicators (more than 20 years on the market, 150-200 employees, the duration of the project 3-4 years) and carry out large-scale projects for the construction of residential complexes in the city. The working experience of all experts is from 2 to 16 years, they participated in both successful and unsuccessful projects and acted in the implementation of the project in one of the main roles - project participant, project manager and project portfolio manager.

While conducting interviews we found the following codes: frequently used words and expressions with the same meaning (Table 1). 
Table 1

Expert opinion codes

\begin{tabular}{|l|l|}
\hline Codes used twice & Codes used three times \\
\hline Changes & Task \\
\hline Experience & Flexibility \\
\hline Interchangeability & Mutual assistance \\
\hline Customer-centricity & Interrelation and trust \\
\hline Coordination & Quality \\
\hline Result maximization & Parties concerned \\
\hline \multirow{2}{*}{ Involvement } & Future benefits \\
\cline { 2 - 2 } & Leader \\
\hline Organization structure & Joint habits \\
\hline Clear regulations & Feedback \\
\hline Purposefulness & Reputation \\
\hline Speed & Profitability \\
\hline Team work & Contact \\
\hline People value & No conflict \\
\hline Timing & Colleagues' respect \\
\hline Relation equality & Profit \\
\hline
\end{tabular}

In total, 32 codes were identified, which were combined into 5 aspect groups according to their substantial aspect:

1) teambuilding;

2) leadership;

3) emphasis on structure;

4) team competence;

5) external communications.

We will consider the aspects and codes included into them in detail.

The first aspect, teambuilding, describes relationships within the team that arise during the project. The coherence degree the project participants' actions allows us to describe such codes as mutual assistance, interrelation and trust, teamwork, coordination, no conflict, joint habits, contact, colleagues' respect.

The second aspect was the project manager's leadership ${ }^{1}$. According to experts, if there is a strong leader, the team purposefully achieves high results. This aspect was made up of the following codes: relation equality within the team, purposefulness, coordination, the presence of a strong leader capable of setting clear tasks, and emphasizing the value of people in the team.

The third aspect, emphasis on structure, reflects the specific structure of the construction organization. The experts

\footnotetext{
${ }^{1}$ In the research project manager and project leader are considered as synonymous.
}

pointed out that in each company there are special regulations for the project implementation. In this aspect, there are clearly expressed codes such as clear objectives, organizational structure, clear rules and regulations, and purposefulness.

The fourth aspect, the team competence, emphasizes how much the professional component of the project team is valued in the company when the construction project is being carried out, as well as the reaction of the manager and team members to changes in the project structure. The codes, responsible for this aspect, are expressed through professionalism, experience, involvement, flexibility, and interchangeability in case of competence incompatibility.

The fifth aspect, external communications, is aimed at the external environment in which the project exists showing the project team flexibility in response to changes in customer preferences. In our opinion, this aspect includes such codes as positive assessment by stakeholders, high profitability, reputation, customer focus, speed, quality, and flexibility.

The success of the project itself is described by future benefits, quality, high profit, corresponding terms, and the project speed.

Based on the identified organizational culture aspects that influence the project success, we compiled a questionnaire to test the hypothesis about the aspects affecting the project success. The questionnaire includes 39 questions and is based on the estimates taken from the seven-step Likert Scale as it allows respondents more accurately express their attitude to a particular judgment.

The questions from the independent variable block "Teambuilding" were based on the expert opinion that successful projects team members spend time together even outside work. They try to help each other, respect colleagues and their opinion, and hardly make personal remarks in discussions and arguments.

Questions of the "Leadership" block were based the thesis that the project manager should also be an informal leader for the project team members so as to inspire, 
evaluate each participant's contribution and set clear goals.

The "Emphasis on structure" block reflects the role of regulations, the other departments and clear tasks in the success of the project.

The "Team Competence" block included questions about expertise, experience and professionalism of the project participants, their enthusiasm and flexibility in working on the project, which subsequently made the block successful.

The questions of the "External Communication" block were aimed to evaluate the project team interaction with external parties, as well as to evaluate the efforts made by the team members to achieve the project's success.

Stage 2 of the study was conducted through Internet surveys in groups of project management professionals on the resources "Vkontakte" and "Linkedin". The posts were preceded by the information that the authors ask to participate in the survey only those members of the groups who work in the field of construction projects.

The survey involved 112 people, including: $53 \%$ of men, $47 \%$ of women; $67 \%$ of respondents at the age of 30 to $50,11 \%$ older than 50 and $25 \%$ under 30 years old. $88 \%$ of the respondents work in companies employing 100 to 250 people. $35 \%$ of the respondents have been working in the project area for 6 to 10 years, with $19 \%$ of the respondents working in this area less than a year. In the sample structure, $48 \%$ were project team members, $31 \%$ project managers, $14 \%$ project portfolio managers and $7 \%$ functional managers.

Having analyzed the demographic profile, we determined a new sample, forming it from the answers of those respondents who matched the conditions we had originally defined: the company with a size of 51 to 250 employees should implement projects in Russia and have a project team of 5 to 8 people. In addition to that, the respondents should have at least one year's experience of working in the current company and project activity. In other words, the sample was maximally standardized, and eventually totaled 80 people.
The responses were analyzed using the method of structural variables:

$$
\left\{\begin{array}{l}
x_{1}=\alpha_{1}+\beta_{1} X+\varepsilon \cdot x_{1} \\
x_{2}=\alpha_{2}+\beta_{2} X+\varepsilon \cdot x_{2} \\
x_{3}=\alpha_{3}+\beta_{3} X+\varepsilon \cdot x_{3} \\
x_{4}=\alpha_{4}+\beta_{4} X+\varepsilon \cdot x_{4}
\end{array}\right.
$$

where $\alpha_{i}-$ constant; $\beta_{i}-$ regression coefficient; $\varepsilon \cdot x_{i}$ - error.

The above formula identified relationship between the project success (dependent variable) and organizational culture aspects (independent variables).

Within the scope of the research, we put forth the following hypotheses:

1. Teambuilding has a positive impact on the project success;

2. Leadership has a positive impact on the project success;

3. Emphasis on structure has a positive impact on the project success;

4. Team competence has a positive impact on the project success;

5. External communication has a positive impact on the project success.

Having constructed the hypotheses all the answerers of the respondents from the final sample were formed into latent constructions and studied with the help of a specialized program to identify statistical matches. Each aspect acted as a latent element, which together with others influenced the success of the project. (Table 2).

We will consider the obtained results

The latent element "Teambuilding" contains 5 basic questions regarding relations within the project team. In Table 2 we see that the reliability level of internal consistency of questions is low (the Cronbach alpha coefficient $\mathrm{Cr} \alpha$ is less than 0.7). This indicates the necessity to correct the questions describing the construct given. The additional reliability index Cre determines the consistency of the questions. Unlike the Cronbach alpha coefficient, it is high for such an element, so we can hardly be certain about the relevance of the questions. The AVE indicator reflects the data convergence and should be higher than 0.5. However, in this element it is lower than the required value, which can also affect the validity of the results. 
Table 2

Identification of statistic matches of the latent elements

\begin{tabular}{|c|c|c|c|c|}
\hline \multirow[t]{2}{*}{ Latent element } & \multicolumn{3}{|c|}{$\begin{array}{l}\text { Test Reliability Level } \\
\text { Assessment }\end{array}$} & \multirow[t]{2}{*}{ Questions and the factor loadings } \\
\hline & Cra & Cre & AVE & \\
\hline \multicolumn{5}{|l|}{ Independent variables } \\
\hline \multirow[t]{5}{*}{ Teambuilding } & \multirow[t]{5}{*}{0.696} & \multirow[t]{5}{*}{0.806} & \multirow[t]{5}{*}{0.463} & Team members spent time together outside work $(0.422)$ \\
\hline & & & & $\begin{array}{l}\text { Mutual assistance was always present among team members } \\
(0.795)\end{array}$ \\
\hline & & & & Team members were respectful to each other $(0.742)$ \\
\hline & & & & Very little / no conflict occurred $(0.640)$ \\
\hline & & & & $\begin{array}{l}\text { Team members communicated constantly throughout the } \\
\text { project }(0.739)\end{array}$ \\
\hline \multirow[t]{4}{*}{$\begin{array}{l}\text { External } \\
\text { Communications }\end{array}$} & \multirow[t]{4}{*}{0.708} & \multirow[t]{4}{*}{0.816} & \multirow[t]{4}{*}{0.528} & $\begin{array}{l}\text { Top executives and customers highly appreciated the team's } \\
\text { performance }(0.642)\end{array}$ \\
\hline & & & & Team sought to meet all customers' expectations $(0.748)$ \\
\hline & & & & Team exceeded project pace $(0.804)$ \\
\hline & & & & $\begin{array}{l}\text { Team members quickly responded environment changes } \\
(0.701)\end{array}$ \\
\hline \multirow[t]{5}{*}{ Leadership } & \multirow[t]{5}{*}{0.781} & \multirow[t]{5}{*}{0.850} & \multirow[t]{5}{*}{0.537} & Manager clearly formulated tasks $(0.512)$ \\
\hline & & & & Manager emphasized value of every team-member $(0.815)$ \\
\hline & & & & Manager was perceived as a leader by project team $(0.797)$ \\
\hline & & & & Manager coordinated the team work well $(0.750)$ \\
\hline & & & & Manager inspired the team to achieve its goals $(0.748)$ \\
\hline \multirow[t]{3}{*}{ Emphasis on structure } & \multirow[t]{3}{*}{0.745} & \multirow[t]{3}{*}{0.853} & \multirow[t]{3}{*}{0.661} & Departments were always ready to help (0.814) \\
\hline & & & & Clear regulation of project work $(0.740)$ \\
\hline & & & & Top management set clear goals and tasks $(0.878)$ \\
\hline \multirow[t]{5}{*}{ Team competence } & \multirow[t]{5}{*}{0.801} & \multirow[t]{5}{*}{0.861} & \multirow[t]{5}{*}{0.557} & The team include professionals $(0.692)$ \\
\hline & & & & $\begin{array}{l}\text { The experience of the team members allowed them to work } \\
\text { more efficient }(0.804)\end{array}$ \\
\hline & & & & The team members were interested in the project $(0.602)$ \\
\hline & & & & $\begin{array}{l}\text { If a person failed he/she was quickly substituted by a more } \\
\text { proficient one }(0.779)\end{array}$ \\
\hline & & & & $\begin{array}{l}\text { The team did not resist changes in case the project benefited } \\
\text { from them }(0.831)\end{array}$ \\
\hline \multicolumn{5}{|l|}{ Dependent variable } \\
\hline \multirow[t]{8}{*}{ Project success } & \multirow[t]{8}{*}{0.838} & \multirow[t]{8}{*}{0.877} & \multirow[t]{8}{*}{0.479} & Project was completed on time or sooner $(0.413)$ \\
\hline & & & & Budget was not exceeded $(0.585)$ \\
\hline & & & & All customers' requirements were fulfilled $(0.675)$ \\
\hline & & & & Customer was satisfied with the result $(0.681)$ \\
\hline & & & & Customer intends to continue cooperation $(0.792)$ \\
\hline & & & & Company became more successful after the project $(0.771)$ \\
\hline & & & & Profit exceeded costs $(0.726)$ \\
\hline & & & & $\begin{array}{l}\text { Project will prove beneficial in the future: new customers } \\
\text { and orders }(0.807)\end{array}$ \\
\hline
\end{tabular}

The "External Communications" latent element includes four questions about the project team interaction with its external environment. As can be seen from Table 2, the factor loadings are below the required level only in the first question, and it can be excluded from the description of the project external communications. The Cronbach alpha coefficient is slightly higher than 0.7 , which reflects a sufficient reliability level of the questions internal consistency. The Cre coefficient is also high.

The latent element "Leadership" consists of five questions reflecting the manager's work during the project and his comprehension as a leader by himself and the team. Table 2 demonstrates that the factor loading of the first question is also below the preferred level of 0.7 , which may indicate the necessity of eliminating this issue from the 
element. The Cronbach alpha coefficients and Cre are much higher than the required levels, which indicates a high reliability level of the questions internal consistency. The AVE indicator is also higher than the desired level. The "Leadership" element can be recognized as valid and convergent.

In the latent element "Emphasis on structure" there are three questions consisting of codes that confirm the importance of regulations and clear indications for the successful project. As it is shown in Table 2, factor loading of all the questions is more than the preferred level of 0.7 , which confirms the element reliability.

The latent element "Team competence" includes five questions concerning the team members' professional qualities shown during the project implementation. In Table 2 the factor loadings of the first and third questions are lower than the required level, so they can be excluded from the final questionnaire. The Cronbach alpha, Cre and AVE coefficients are higher than the preferred levels, which indicates the construct reliability.

The latent element "Project success" is a dependent variable that consists of eight basic questions, including both the "iron triangle" and additional definitions of success. Table 2 shows the main characteristics of the interrelation between the questions as well as the elements of the aspects and project success. Factor loadings of only some questions are greater than the preferred level of 0.7. The Cronbach alpha coefficient is 0.838 , which demonstrates a high reliability level of internal consistency of questions. The Cre indicator also confirms this consistency. However, AVE is less than the required value, which may negatively affect the validity of the results.

The following results were obtained:

$y=0,279 x_{1}+0,371 x_{2}+0,492 x_{3}-$ $-0,217 x_{4}-0,102 x_{5}\left(R^{2}=0,611 ; R_{a d j}^{2}=0,585\right)$, where $x_{1}$ - teambuilding; $x_{2}$ - external communications; $x_{3}$ - leadership; $x_{4}-$ team competence; $x_{5}$ - emphasis on structure.

Two aspects - "Team Competence" and "Emphasis on Structure" - are detrimental to the project success, while the remaining aspects have a fairly significant impact. The aspect
"Leadership" has the most significant impact and it has been confirmed by foreign scholars.

To assess the overall impact on the project success of all organizational culture aspects, considered in terms of latent designs, we use the determination coefficient $R^{2}$. It is a linear relationship characteristic in regression analysis that is calculated using the Smart PLS statistical software package. The measure can take values between zero and one, with zero meaning no linear relationship. As we can see, $R^{2}$ is above zero $(0.611)$, which indicates a fairly strong linear relationship between the variable "Project Success" and the explanatory variables - external communications, teambuilding, emphasis on structure and team competence.

Thus, we can conclude that two out of five hypotheses have not been confirmed. However, teambuilding, external communication and leadership have a significant impact on the success of the project. Our study has shown the need to correct the results in order to identify valid and convergent issues in the new conditions of influence of selected aspects of organizational culture on the success of the project.

Adjustment of the OCPS method for the assessment of Russian construction projects

The suggested method considers
national peculiarities of business
in any country. And in our opinion it is significant since institutional features of both formal and informal nature have a significant impact on the behaviour of the project team and the quality of project activities. In this regard, the use of a strictly fixed questionnaire can lead to distortion of the results, ignoring important features of interaction within a certain institutional unit and will not allow making adequate conclusions. Considering the peculiarities of the Russian practice of organizations in the construction industry, it was also necessary to adjust the basic OCPS method.

To obtain a reliable questionnaire with related questions, it is necessary to identify by selecting the necessary list to determine the impact of aspects of organizational culture on the success of a construction project. 
The first step in the adjustment of the methodological issues was to exclude the aspects "Emphasis on Structure" and "Team Competency". The negative relationship of these aspects with the success of a project may be due to the specifics of projects in Russian construction companies, the wrong perception of respondents of the proposed questions, and the erroneous combination of codes from interviews into aspects.

After removing the two variables, $R^{2}$ decreased from 0.611 to 0.582 , which characterizes the negative dynamics of the relationship between latent elements. However, the links between independent aspects and dependent success have also decreased: teambuilding 0.244 , external communications 0.212 , leadership 0.439 .

In order to strengthen all internal ties, it is necessary to adjust the issues themselves.

All questions which factor loads were less than 0.7 were removed from the latent elements. However, after calculations we have revealed that it leads to the decrease of the coefficients of internal consistency and convergence to a critical state. Thus, a new selection of questions included in the elements was made (Table 3).

Table 3

Identification of statistic matches of the latent elements of the project success considering the survey question correction

\begin{tabular}{|c|c|c|c|c|}
\hline \multirow[t]{2}{*}{ Latent element } & \multicolumn{3}{|c|}{$\begin{array}{c}\text { Test Reliability Level } \\
\text { Assessment }\end{array}$} & \multirow[t]{2}{*}{ Questions and the factor loadings } \\
\hline & Cra & Cre & AVE & \\
\hline \multicolumn{5}{|c|}{ Independent variables } \\
\hline \multirow[t]{4}{*}{ Teambuilding } & \multirow[t]{4}{*}{0.739} & \multirow[t]{4}{*}{0.833} & \multirow[t]{4}{*}{0.557} & $\begin{array}{l}\text { Mutual assistance was always present among team } \\
\text { members }(0.787)\end{array}$ \\
\hline & & & & Team members were respectful to each other $(0.760)$ \\
\hline & & & & Very little / no conflict occurred $(0.652)$ \\
\hline & & & & $\begin{array}{l}\text { Team members communicated constantly throughout the } \\
\text { project }(0.778)\end{array}$ \\
\hline \multirow[t]{4}{*}{$\begin{array}{l}\text { External } \\
\text { Communications }\end{array}$} & \multirow[t]{4}{*}{0.708} & \multirow[t]{4}{*}{0.816} & \multirow[t]{4}{*}{0.528} & $\begin{array}{l}\text { Top executives and customers highly appreciated the } \\
\text { team's performance }(0.643)\end{array}$ \\
\hline & & & & Team sought to meet all customers' expectations $(0.742)$ \\
\hline & & & & Team exceeded project pace $(0.799)$ \\
\hline & & & & $\begin{array}{l}\text { Team members quickly responded environment changes } \\
(0.713)\end{array}$ \\
\hline \multirow[t]{4}{*}{ Leadership } & \multirow[t]{4}{*}{0.794} & \multirow[t]{4}{*}{0.866} & \multirow[t]{4}{*}{0.618} & Manager emphasized value of every team-member $(0.826)$ \\
\hline & & & & Manager was perceived as a leader by project team $(0.791)$ \\
\hline & & & & Manager coordinated the team work well $(0.771)$ \\
\hline & & & & Manager inspired the team to achieve its goals $(0.754)$ \\
\hline \multicolumn{5}{|l|}{ Dependent variable } \\
\hline \multirow[t]{6}{*}{ Project success } & \multirow[t]{6}{*}{0.848} & \multirow[t]{6}{*}{0.887} & \multirow[t]{6}{*}{0.570} & All customers' requirements were fulfilled $(0.650)$ \\
\hline & & & & Customer was satisfied with the result $(0.685)$ \\
\hline & & & & Customer intends to continue cooperation (0.776) \\
\hline & & & & Company became more successful after the project (0.776) \\
\hline & & & & Profit exceeded costs $(0.753)$ \\
\hline & & & & $\begin{array}{l}\text { Project will prove beneficial in the future: new customers } \\
\text { and orders }(0.840)\end{array}$ \\
\hline
\end{tabular}

As can be seen in Table 3, in all cases the Cronbach alpha coefficients have increased, which confirms the stronger consistency of the questions within the element than in the previous one. The Cre reliability coefficient has increased in teambuilding and leadership, but remains the same in external communications. The AVE indicator has also increased in teambuilding and leadership, which confirms the convergence of questions within the elements.

All factor loadings are above the required 0.7, except for some questions. These elements have been decided to leave unchanged, since the removal of any question 
is bound to jeopardize the relationship between the remaining questions.

Table 3 presents all the coefficients, which were obtained when the first two questions, having the least factor loads - less than 0.5 , were removed. In comparison with the original design, the Cronbach alpha coefficient, reliability and convergence factors have also increased. This enables us to believe that the proposed set of questions properly describes the "Project success" element.

The final result of data validation and finding a connection between them can be presented as follows: $=0,584)$,

$$
y=0,212 x_{1}+0,188 x_{2}+0,488 x_{3}\left(R^{2}=\right.
$$

where $x_{1}-$ teambuilding; $x_{2}-$ external communications; $x_{3}$ - leadership.

Despite the fact that relations with latent elements do not achieve the initial values, we may confirm that all factor loads have increased to the required values, with all coefficients - from the Cronbach alpha coefficient to the AVE indicator - within the required limits. Thus, we have validated the questionnaire, which can currently be used in the study of aspects of the impact of organizational culture on the success of the project in Russian companies.

Having identified the main factors of organizational culture that influence the project success, we believe that it is necessary to adjust the criteria for assessing the success in Russian construction projects. Initially, when formulating meaningful elements of research tools, we focused on the following criteria for the project success: its effectiveness, impact on the consumer, business success and future benefits. However, the statistical analysis has shown that the conventional indicators of project success (according to A. Shenhar and D. Dvir): exceeding the budget and project deadlines are not criteria for project success in the construction sector in the context of organizational culture.

We recommend using the following criteria to assess the project success:

- customer satisfaction (the indicators are reputation of a company, customer loyalty, the ratio of technical specifications with the final result of the project);

- business success (the indicators are market share, profit, profitability);

- future benefits (the indicators are number of new orders, improvement of project technologies and methodologies).

We believe the criteria will make the assessment of project success in construction industry more complex and accurate and will reveal its disadvantages.

Having identified the major influential factors of organizational culture on the project success, we developed the success matrix of the Russian construction project (Table 4).

Table 4

Matrix of project success levels

\begin{tabular}{|c|c|c|c|}
\hline Success level & Teambuilding & Leadership & External communications \\
\hline $\begin{array}{l}\text { Successful } \\
\text { project }\end{array}$ & $\begin{array}{l}\text { Conflict-free communication } \\
\text { between project team members, } \\
\text { active mutual assistance }\end{array}$ & $\begin{array}{l}\text { Manager emphasizes the team } \\
\text { value; work is coordinated and } \\
\text { does not require management } \\
\text { intervention }\end{array}$ & $\begin{array}{l}\text { Team works quickly, meets the } \\
\text { customer, responds quickly to } \\
\text { changes in the external } \\
\text { environment and project } \\
\text { requirements }\end{array}$ \\
\hline $\begin{array}{l}\text { Unsuccessful } \\
\text { project }\end{array}$ & $\begin{array}{l}\text { Recurrent conflicts occur, but } \\
\text { quickly resolved under the } \\
\text { influence of mutual respect; team } \\
\text { members are not afraid to seek } \\
\text { help from colleagues in emergency }\end{array}$ & $\begin{array}{l}\text { The manager has difficulty in the } \\
\text { competent work coordination, } \\
\text { but team members help him, } \\
\text { perceive as a leader, and are } \\
\text { focused on achieving the } \\
\text { project's goal }\end{array}$ & $\begin{array}{l}\text { The team acts according to the } \\
\text { plan, tries to meet all the } \\
\text { customer's requirements, but does } \\
\text { not responds to the environment } \\
\text { challenges quickly enough }\end{array}$ \\
\hline Failing project & $\begin{array}{l}\text { Constant conflicts; lack of mutual } \\
\text { respect and mutual assistance }\end{array}$ & $\begin{array}{l}\text { The team does not perceive the } \\
\text { project manager as a leader, fails } \\
\text { to keep to the schedule; manager } \\
\text { fails to coordinate the team work }\end{array}$ & $\begin{array}{l}\text { The team does not respond to the } \\
\text { external environment, ignores } \\
\text { communication with customers, } \\
\text { delays the project implementation }\end{array}$ \\
\hline
\end{tabular}


In Table 4 the ratio of success factors and success rates makes the manager aware of what is happening at this stage in the project life cycle. The success matrix acts as an indicator of the project team status when implementing construction projects. Using this matrix, the manager can quickly respond to the deterioration of the project organizational culture and modify it to achieve the project's objectives and its success.

\section{Conclusion}

7 he research of the aspects of organizational culture from the

1 view point of their impact on the project success is a new theme gaining popularity. Since the 2000s the scholars researching project management have addressed not only the technological, technical and organizational success factors, but also the rhetorical and symbolic ones, which also include the organizational culture of the project.

The method developed on the basis of those suggested by J.D. Wilfong, M. Latonio, A. Shenhar, P. Patanakul and Z.H. Aronson has been tested in the case study of construction industry. The tree main aspects affecting the project success were reviled there - internal communications, leadership, and external communications.

By conducting a two-stage study, only part of the hypotheses was confirmed.

First, we have proven that in contrast to the results of M. Latonio, J.M. Morrison, C.J. Brown and E.M. Smit the number of the aspects of organizational culture that really affects the success of Russian projects in the construction sector, is much less, but the fundamental role of leadership in the project success has also been confirmed.

Secondly, the project success in the Russian construction sector is tied up with the way the end user and the customer react to the project result. Exceeding the budget or deadlines does not become a critical aspect of project success, while the desire to continue cooperation with the company that implemented the project is one of the key success factors.
The baseline results of the present research enable us to develop the image of an ideal organizational culture that meets major basic requirements:

1. In the ideal culture of the project, the manager acts not only as a formal leader, but also as an informal one, emphasizing the value of team members, as well as being able to coordinate the work of the team and inspire achievement of new goals;

2. Ideal culture is distinguished by a developed network of internal communications and emphasis on teamwork. Team members should be able to interact as equal players, seeking to maximize the result by mutual assistance, building respectful relationships that help achieve the project goal;

3. The ideal culture of the project connects the team with stakeholders by means of a network of active external communications. This reduces mistrust and allows building strong ties with the customer as well as timely adjusting the project specifications in order to achieve the maximum result.

The article also presents a matrix of success levels. The application of the matrix will help quickly to respond to the problems that exist in the project team.

From practical view point, the method that reveals the influential aspects of organizational culture will form a clear vision of the "symbolic" factors that have a significant impact on the success of the project. The method considers the achievements of foreign scientists and at the same time the Russian specifics of doing business, and also allows planning the necessary management impact on the significant success factors of the project.

To test the suggested method at project organizations operating in other branches of economy seems to be reasonable as the results that will be obtained during the approbation will improve and verify the method in the context of any organization functioning in other spheres or branches of economy. 


\section{References}

1. Armenakis A.A., Gregory B.T., Harris S.G., Shook C.L. Organizational culture and effectiveness: A study of values, attitudes, and organizational outcomes. Journal of Business Research, 2009, vol. 62, iss. 7, pp. 673-679.

2. Denison D., Nieminen L., Kotrba L. Diagnosing organizational cultures: A conceptual and empirical review of culture effectiveness surveys. European Journal of Work and Organizational Psychology, 2012, vol. 23, no. 1, pp. 1-17.

3. Ogbonna E., Harris L.C. Leadership style, organizational culture and performance: Empirical evidence of UK companies. International Journal of Human Resource Management, 2000, vol. 11, iss. 4, pp. 766-788.

4. Gordon G.G., Ditomaso N. Predicting corporate performance from organizational culture. Journal of Management Studies, 1992, vol. 29, no. 6, pp. 783-798.

5. Calori R., Sarnin Ph. Corporate culture and economic performance: A French Study. Organization Studies, 1991, vol. 12, no. 1, pp. 49-74.

6. Kotrba L.M., Gillespie M.A., Schmidt A.M., Smerek R.E., Ritchie S.A., Denison D.R. Do consistent corporate cultures have better business performance? Exploring the interaction effects. Human Relations, 2012, vol. 65, no. 2, pp. 241-262. doi: 10.1177/0018726711426352.

7. Davis K. Different stakeholder groups and their perceptions of project success. International Journal of Project Management, 2014, no. 32, iss. 2, pp. 189-201.

8. Morris P.W.G., Hough G. The Anatomy of major projects: A study of the reality of project management. Chichester, Wiley, 1987. 338 p.

9. Kerzner H., Saladis F.P. Value-driven project management. Wiley series in project management. New-York, John Wiley and Sons, Inc., Hoboken, 2009. 291 p.

10. Rolstadas A. Applied project management - How to organize, plan and control projects. Trondheim, Tapir Academic Press, 2008. 387 p.

11. Shenhar A., Dvir D. Project management research: The challenge and opportunity. Project Management Journal, 2007, vol. 38, no. 2, pp. 93-99.

12. Ika L.A. Project success as a topic in project management journals. The Journal of the Academy of Management, 2009, vol. 40, no. 4, pp. 6-19. doi: 10.1002/pmj.2013.

13. Nguyen L.D., Ogunlana S.O., Lan D.T.X. A study on project success factors in large construction projects in Vietnam. Engineering, Construction and Architectural Management, 2004, vol. 11, iss. 6, pp. 404-413. doi: 10.1108/09699980410570166.

14. Iyer K.C., Jha K.N. Critical factors affecting schedule performance: Evidence from Indian construction projects. Journal of Construction Engineering and Management, 2006, vol. 132, iss. 8, pp. 871-881.

15. Jo P.A., Barry M.L. The most important success factors for implementation of government projects in developing countries. Portland International Conference on Management of Engineering and Technology, 2008, 27-31 July, pp. 1400-1409.

16. Yu J.H., Kwon H.R. Critical success factors for urban regeneration projects in Korea. International Journal of Project Management, 2011, vol.29, iss. 7, pp. 889-899.

17. Yong Y.C., Mustaffa N.E. Analysis of factors critical to construction project success in Malaysia. Engineering, Construction and Architectural Management, 2012, vol. 19, iss. 5, pp. 543-556.

18. Howsawi E., Eager D., Bagia R., Niebecker K. A success model for project management during national crises. International Review of Management and Business Research, 2014, vol. 3, iss. 2, pp. 960-981.

19. Iroanya C.C. The relationship between organizational culture and quality of communication in project management. Doctoral Dissertation. Retrieved from ProQuest Dissertations and Theses. 2012. 188 p.

20. Kendra K.A. An organizational design approach to project management. Doctoral Dissertation. Retrieved from ProQuest Dissertations and Theses. 2003. 180 p.

21. Morrison J.M., Brown C.J., Smit E.M. A supportive organizational culture for project management in matrix organizations: A theoretical perspective. South African Journal of Business Management, 2006, vol. 39, iss. 4, pp. 39-54.

22. Latonio M. Exploring the impact of organizational culture on project management: Aphenomenological study. Doctoral Dissertation. Retrieved from ProQuest Dissertations and Theses. 2007. 362 p.

23. Aronson Z.H., Shenhar A.J., Patanakul P. Managing the intangible aspects of a project: The effect of vision, artifacts, and leader values on project spirit and success in technology-driven projects. Project Management Journal, 2013, vol. 44, no. 1, pp. 35-58. doi: 10.1002/pmj.21322. 
24. Wilfong J.D. Organizational culture and Information technology [IT] project success and failure factors: A mixed-methods study using the competing values framework and Schein's three levels approach. San Francisco. CA, 2014. 235 p.

25. Braun V., Clarke V. Using thematic analysis in psychology. Qualitative Research in Psychology, 2006, no. 3, pp. 77-101.

Received June 06, 2019; accepted September 25, 2019

\section{Information about the Authors}

Isopeskul' Ol'ga Yur'evna - Candidate of Economic Sciences, Associate Professor, Dean of the Faculty of Economics, Management and Business Informatics, National Research University Higher School of Economics (38, Studencheskaya st., Perm, 614070, Russia; e-mail: oisopeskul@ hse.ru).

Ponomarenko Ekaterina Aleksandrovna - Master Student, Faculty of Economics, Management and Business Informatics, National Research University Higher School of Economics (38, Studencheskaya st., Perm, 614070, Russia; e-mail: wittmannekaterina@gmail.com).

\section{Список литературы}

1. Armenakis A.A., Gregory B.T., Harris S.G., Shook C.L. Organizational culture and effectiveness: A study of values, attitudes, and organizational outcomes // Journal of Business Research. 2009. Vol. 62, Iss. 7. P. 673-679.

2. Denison D., Nieminen L., Kotrba L. Diagnosing organizational cultures: A conceptual and empirical review of culture effectiveness surveys // European Journal of Work and Organizational Psychology. 2012. Vol. 23, № 1. P. 1-17.

3. Ogbonna E., Harris L.C. Leadership style, organizational culture and performance: Empirical evidence of UK companies // International Journal of Human Resource Management. 2000. Vol. 11, Iss. 4. P. 766-788.

4. Gordon G.G., Ditomaso N. Predicting corporate performance from organizational culture // Journal of Management Studies. 1992. Vol. 29, № 6. P. 783-798

5. Calori R., Sarnin Ph. Corporate culture and economic performance: A French Study // Organization Studies. 1991. Vol. 12, № 1. P. 49-74.

6. Kotrba L.M., Gillespie M.A., SchmidtA.M., Smerek R.E., Ritchie S.A., Denison D.R. Do consistent corporate cultures have better business performance? Exploring the interaction effects // Human Relations. 2012. № 65 (2). P. 241-262. doi: 10.1177/0018726711426352.

7. Davis K. Different stakeholder groups and their perceptions of project success // International Journal of Project Management. 2014. № 32, Iss. 2. P. 189-201.

8. Morris P.W.G., Hough G. The Anatomy of major projects: A study of the reality of project management. Chichester: Wiley, 1987. 338 p.

9. Kerzner H., Saladis F.P. Value-driven project management. Wiley series in project management. New-York: John Wiley \& Sons, Inc., Hoboken, 2009. 291 p.

10. Rolstadas A. Applied project management - How to organize, plan and control projects. Trondheim: Tapir Academic Press, 2008. 387 p.

11. Shenhar A., Dvir D. Project management research: The challenge and opportunity // Project Management Journal. 2007. Vol. 38, № 2. P. 93-99.

12. Ika L.A. Project success as a topic in project management journals // The Journal of the Academy of Management. 2009. Vol. 40, № 4. P. 6-19. doi: 10.1002/pmj.2013.

13. Nguyen L.D., Ogunlana S.O., Lan D.T.X. A study on project success factors in large construction projects in Vietnam // Engineering, Construction and Architectural Management. 2004. Vol. 11, Iss. 6. P. 404-413. doi: 10.1108/09699980410570166.

14. Iyer K.C., Jha K.N. Critical factors affecting schedule performance: Evidence from Indian construction projects // Journal of Construction Engineering and Management. 2006. Vol. 132, Iss. 8. P. 871-881. 
15. Jo P.A., Barry M.L. The most important success factors for implementation of government projects in developing countries // Portland International Conference on Management of Engineering and Technology. 2008, 27-31 July. Portland, 2008. P. 1400-1409.

16. YuJ.H., Kwon H.R. Critical success factors for urban regeneration projects in Korea // International Journal of Project Management. 2011. Vol. 29, Iss. 7. P. 889-899.

17. Yong Y.C., Mustaffa N.E. Analysis of factors critical to construction project success in Malaysia // Engineering, Construction and Architectural Management. 2012. Vol. 19, Iss. 5. P. 543-556.

18. Howsawi E., Eager D., Bagia R., Niebecker K. A success model for project management during national crises // International Review of Management and Business Research. 2014. Vol. 3, Iss. 2. P. 960-981.

19. Iroanya C.C. The relationship between organizational culture and quality of communication in project management: Doctoral Dissertation. Retrieved from ProQuest Dissertations and Theses. 2012. 188 p.

20. Kendra K.A. An organizational design approach to project management: Doctoral Dissertation. Retrieved from ProQuest Dissertations and Theses. 2003. 180 p.

21. Morrison J.M., Brown C.J., Smit E.M. A supportive organizational culture for project management in matrix organizations: A theoretical perspective // South African Journal of Business Management. 2006. Vol. 39, Iss. 4. P. 39-54.

22. Latonio M. Exploring the impact of organizational culture on project management: A phenomenological study: Doctoral Dissertation. Retrieved from ProQuest Dissertations and Theses. 2007. $362 \mathrm{p}$.

23. Aronson Z.H., Shenhar A.J., Patanakul P. Managing the intangible aspects of a project: The effect of vision, artifacts, and leader values on project spirit and success in technology-driven projects // Project Management Journal. 2013. Vol. 44, № 1. P. 35-58. doi: 10.1002/pmj.21322.

24. Wilfong J.D. Organizational culture and Information technology [IT] project success and failure factors: A mixed-methods study using the competing values framework and Schein's three levels approach. San Francisco. CA, 2014. 235 p.

25. Braun V., Clarke V. Using thematic analysis in psychology // Qualitative Research in Psychology. 2006. № 3. P. 77-101.

Статья поступила в редакцию 06.06.2019, принята к печати 25.09.2019

\section{Сведения об авторе}

Исопескуль Ольга Юрьевна - кандидат экономических наук, доцент, декан факультета экономики, менеджмента и бизнес-информатики, Национальный исследовательский университет «Высшая школа экономики» - Пермский филиал (Россия, 614070, г. Пермь, Студенческая, 38; e-mail: oisopeskul@hse.ru).

Пономаренко Екатерина Александровна - магистр, факультет экономики, менеджмента и бизнес-информатики, Национальный исследовательский университет «Высшая школа экономики» Пермский филиал (Россия, 614070, г. Пермь, Студенческая, 38; e-mail: wittmannekaterina@gmail.com).

\footnotetext{
Просьба ссылаться на эту статью в русскоязычных источниках следующим образом: Isopeskul' O.Yu., Ponomarenko E.A. Research methodology for the assessment of the influence of organizational culture aspects on project success // Вестник Пермского университета. Cep. «Экономика» = Perm University Herald. Economy. 2019. Том 14. № 3. С. 495-512. doi: 10.17072/1994-9960-2019-3-495-512
}

\section{Please cite this article in English as:}

Isopeskul' O.Yu., Ponomarenko E.A. Research methodology for the assessment of the influence of organizational culture aspects on project success. Vestnik Permskogo universiteta. Seria Ekonomika $=$ Perm University Herald. Economy, 2019, vol. 14, no. 3, pp. 495-512. doi: 10.17072/1994-9960-2019-3-495-512 